\title{
A CASE REPORT OF CORONAVIRUS DISEASE (COVID-19).
}

\author{
Vityala Yethindra ${ }^{1}$ and Tugolbai Tagaev ${ }^{1}$ \\ ${ }^{1}$ International School of Medicine
}

May 6, 2020

\begin{abstract}
The coronavirus disease (COVID-19) outbreak associated with SARS-CoV-2 was reported in December 2019 in Wuhan, China, causing a global pandemic. We report a 36-year-old male presenting with fever, a five-day dry cough, and clinical symptoms of pneumonia. His diagnosis and treatment are described.
\end{abstract}

\section{Hosted file}

COVID-19 case Wiley.docx available at https://authorea.com/users/317811/articles/447912-acase-report-of-coronavirus-disease-covid-19

\section{REFERENCES}

1. Söderlund-Venerumo, M., Brown, K.E., and Erdman D.D. Human Parvoviruses. In: Richman, D. D., Whitley, R. J., and Hayden, F. G., eds. Clinical Virology, 4th ed. Washington, DC: ASM Press; 2016. 679-699 pp.

2. Chen, F., Knutson, T. P., Rossow, S., Saif, L. J., and Marthaler, D. G. 2019. Decline of transmissible gastroenteritis virus and its complex evolutionary relationship with porcine respiratory coronavirus in the United States. Scientific Reports 9:3953.

3. Marthaler, D., Raymond, L., Jiang, Y., Collins, J., Rossow, K., and Rovira, A. 2014. Rapid detection, complete genome sequencing, and phylogenetic analysis of porcine deltacoronavirus. Emerging Infectious Diseases 20:1347-1350.

4. Shapiro, M., London, B., Nigri, D., Shoss, A., Zilber, E., and Fogel, I. 2016. Middle East respiratory syndrome coronavirus: review of the current situation in the world. Disaster and Military Medicine 2:9.

5. Li, Q., Guan, X., Wu, P., et al. 2020. Early transmission dynamics in Wuhan, China, of novel coronavirus-infected pneumonia. New England Journal of Medicine 382:1199-1207.

6. Guan, W. J., Ni, Z. Y., Hu, Y., et al. 2020. Clinical characteristics of coronavirus disease 2019 in China. New England Journal of Medicine 382:1708-1720.

7. Lauer, S. A., Grantz, K. H., Bi, Q., et al. The incubation period of coronavirus disease 2019 (COVID19) from publicly reported confirmed cases: Estimation and application [published online ahead of print March 10, 2020]. Annals of Internal Medicine. doi: 10.7326/M20-0504.

8. Huang, P., Liu, T., Huang, L., et al. 2020. Use of chest CT in combination with negative RT-PCR assay for the 2019 novel coronavirus but high clinical suspicion. Radiology 295:22-23. 

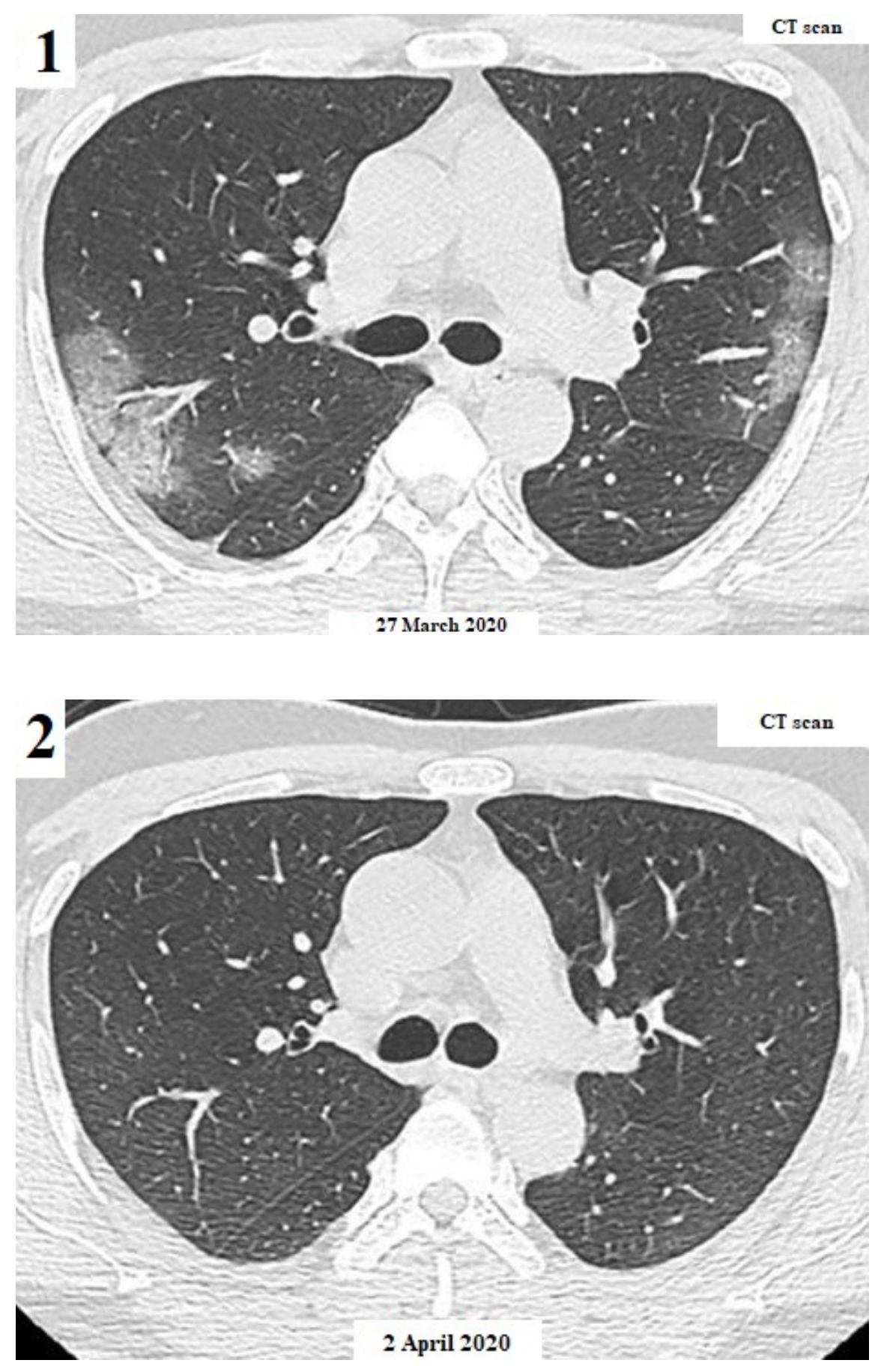